\title{
Ergonomics analysis of the activity of boning shoulder in a pig slaughter-house in the city of Ipiranga-SC
}

\author{
Lizandra Garcia Lupi Vergara ${ }^{\mathrm{a}}$ and Thaís Regina Pansera ${ }^{\mathrm{b}}$ \\ ${ }^{a}$ Production and Systems Engineering Department, Federal University of Santa Catarina, Campus Universitário \\ Reitor João David Ferreira Lima Trindade, CEP: 88040-970, Florianópolis, SC, Brazil \\ ${ }^{b}$ Post-graduate course in Work Safety Engineering. Community University of Chapecó, Rua Senador Attílio \\ Fontana, 591-E, Bairro Efap, CEP: 89809-000, Chapecó, SC, Brazil
}

\begin{abstract}
The incidence of workers suffering from occupational injuries has alerted health professionals and entrepreneurs. Enterprises are looking for improvements in production systems by investments in quality, technological innovations and in human resources that are capable and committed to the objectives and targets of the enterprise. This research was developed in a pig slaughter-house in the city of Ipiranga-SC, in the labor of boning shoulder of the pig, because this is the activity that presents more registers of complaints of pain and also probability of development of occupational diseases with cause in the enterprise.Tools of Ergonomics Analysis of Work were used, from interviews with workers to the application of LEST method in the activity analyzed. The necessity of immediate intervention in the work station was shown in the results, because of the high risk of prejudice to the health of the workers. Improvement actions must be done to satisfy the ergonomics requirements of NR 17 standard, attending the enterprise interests in the occupational diseases prevention.
\end{abstract}

Keywords: ergonomics, LEST method, safety, health

\section{Introduction}

The worker should be aware of preventative actions in terms of occupational health, such as those established by specific norms, for example, the Brazilian norm NR 17/1990 - Ergonomics, [10] which aims to establish parameters which allow the adaptation of the working conditions to the physicalphysiological characteristics of the workers, so as to provide maximum comfort, safety and performance efficiency.

Work-related Musculoskeletal Disorders (WMSD) are not a disease of modern times, they are associated with activities involving repetitive movements since the seventeenth century. [8] However, after the Industrial Revolution there was a significant increase in the number of clinical cases reported and there were several epidemics.

In Brazil there is currently an epidemic of WMSD and about the prevalence of WMSD, [7] it was found that most research focuses on urban work and relates the disease especially in industries with repetitive line production where the work had intensified and remuneration is based on productivity.

The city of Itapiranga-SC, Brazil, has as farming economic base, with emphasis on poultry, cattle, milk, pig production, tobacco and maize cultivation of various agricultural products. The jobs bases are in manufacturing industry, which comprises the agribusiness, slaughter houses and derivatives. The largest agribusiness installed in the city has approximately 3.000 employees and operates in the business of exporting birds and pigs.

The choice of the theme comes in meeting with the reality of the city, large agribusiness with high production number, having in its frame problems of complaints of pain and repetitiveness in labor activity.

[2] Lameira et al investigated the influence of hand posture (prone or supine) on the judgment process of the handedness of a pictured hand to verify how and whether proprioceptive postural information influenced this judgment. The study suggested the dis- 
crete changes in body posture (hand in the prone or supine position) and the maintenance of the same movement during response enabled a more specific understanding of the importance of the proprioceptive information in the processes of motor imagery.

As Application Handbook NR 17, the ergonomics analysis is a constructive and participatory process for solving a complex problem that requires knowledge of the tasks of the activity undertaken to accomplish them and difficulties to achieve performance and productivity requirements. The activities developed by man to meet the conditions of work are translated into a workload that depending on the motivation, skills, physical capabilities, cognitive, emotional state, among others.

This research was developed in a pig slaughterhouse in the city of Itapiranga-SC, in the labor of boning shoulder of the pig in order to improve the conditions of the job, comfort and satisfaction of workers.

\section{Methodological procedures}

The methodological procedure comprised a qualitative study, based on a literature review of the subject, followed by a description of the problem through a case study applied at a pig slaughter-house in Santa Catarina State, Brazil.

The proposed tool was the Ergonomics Analysis of Work (AET) through the steps:

- Apply the tool AET in the activity of boning shoulder of the pig, using as support the LEST Method;

- Guiding modifications of working conditions on the critical points that were highlighted in the analysis AET;

- Propose recommendations for improvements relating to safety, productivity and quality of products or services.

In the data collection it was made noise, vibration, temperature and luminosity measurements and it was also applied questionnaires, investigations and interviews with the workers to collect data, such as: postures evaluation, efforts, relationship with the command, work accidents, among others.

\subsection{The LEST method}

The method used to evaluate the ergonomics problems was the [9] LEST Method - Laboratoire d'Economie et Sociologie du Travail, developed in 1978, with the goal of evaluate labor conditions classifying them as: satisfactory, uncomfortable or harmful, detaching the factors that may have influence in the health and in the personal life of the workers. To accomplish the ergonomics diagnosis fourteen variables grouped into six aspects are considerate: Physical load, Physical environment, Mental load, Psychosocial aspects, Social Status and Labor time.

From the collected results, data were analysed by LEST program, obtaining a diagnosis of the more relevant problems that affect the employees to propose better labor and health conditions of work.

\section{Ergonomics analysis}

Ergonomics analysis is not restricted to the analysis of work prescribed whose goals and methods are defined for instructions. From the work prescribed workers organize their activities, due to multiple factors. The collect of the data was conducted through the stages of ergonomic analysis: analysis of the demands, task analysis, analysis activities, diagnosis and ergonomic recommendations.

\subsection{Analysis of the demands}

According the Medical Service of the enterprise the function that had the highest record of complaints of pain was the line of the palette, palette specifically for boning shoulder of the pig.

The medical field and ergonomic studies indicate that the standing posture and sitting are sometimes accompanied by pain in the muscles and connective tissues of tendons, joint capsules and ligaments.

There is evidence that such pain, can become the symptoms of chronic diseases and rheumatic order. For the complaint is validated and recorded was by following criteria: (i) have causal link with the work; (ii) have employees with at least three months in the role of boning.

After lifting the job with biggest complaint, the study verified the part of the body most frequently hit records of complaints. So, the body parts with higher incidence of record are: wrist, shoulder and lumbar spine, and should be analysed and focused in ergonomics improvements.

\subsection{Task analysis}

The industry of bonning room is subdivided into four lines: palette line, line of carré, belly line and 
row of shank. The largest record of complaint of pain is the line from the palette.

The Figure 1 shows the layout of the line in the palette with emphasis on activities of Boning and process flow.

The room has presence of machinery and equipment (treadmills, trhimmers, saws tapes, among others) for the development of activity with more preci- sion and less physical effort. In Figure 1 is located the positions of employees who perform the activity of the boning of the palette. Environment with temperature between 10 to $13^{\circ}(\mathrm{C})$, possessing good lighting (670 LUX) and average noise of $91 \mathrm{~dB}$.

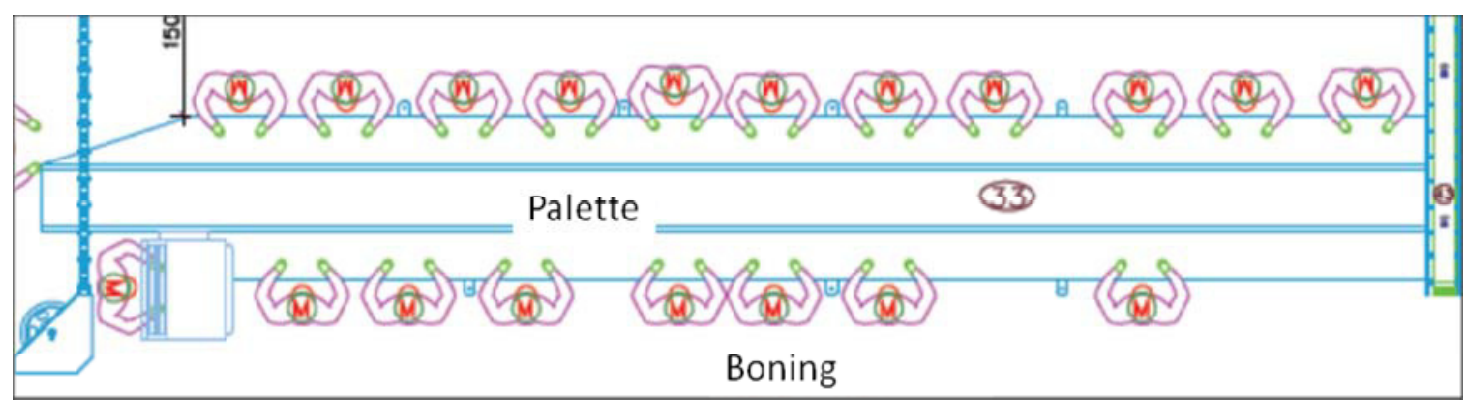

Figure 1. Line Layout Palette with emphasis on activities of boning and process flow

Source: The author

The population was composed of individuals surveyed 06 , totaling $100 \%$ of workers who perform the function palette boning in the second round of work. With ethical care, participants were informed about the objectives of the study by signing a term of consent. The production volume is 1500 /day pigs, with 125 employees in the sector of boning, the work shift occurs from 06:20 to 12:00 - 01:00 pm-04:08 pm, possessing 4 breaks during the journey ( 2 breaks of $10 \mathrm{~min}$ and 2 breaks of $8 \mathrm{~min}$, more lunch break of $76,3 \mathrm{~min}$ ). The characteristics of the work situation in post-boning are presented in Table 1.

Table 1

Characteristics of the work situation in post-boning

\begin{tabular}{|l|l|}
\hline ENVIRONMENTAL NOISE & $91 \mathrm{~dB}$ \\
\hline LIGHT ENVIRONMENT & 670 LUX \\
\hline RISK OF INJURY & Absent vibration environment \\
\hline ERGONOMIC RISK & $\begin{array}{l}\text { Cout, Bruising; Fall same level } \\
\text { Repeatability, postures reviews }\end{array}$ \\
\hline FACTORS RELATED TO THE ACTIVITY & $\begin{array}{l}500 \text { pigs per day } 1 \text { st shift } \\
1500 \text { pigs per day } 2 \text { nd shift }\end{array}$ \\
\hline CYCLE TIME & $\begin{array}{l}49 \text { seconds between one and another, takes } \\
36 \text { seconds to a handle, debone and return, } 5 \\
\text { seconds to chair every three paltes on } \\
\text { average, and } 8 \text { seconds until the next palette }\end{array}$ \\
\hline NUMBER OF HANDLES & $\begin{array}{l}500 \text { PIECES Movement for palettes in the } \\
\text { second round and 400 pallets in the fir st } \\
\text { round }\end{array}$ \\
\hline JOBS St atic & $\begin{array}{l}\text { USED FO OT PROTECTIONS: PVC Boots, Lined } \\
\text { The } \text { mal Socks } \\
\text { HANDS: Latex gloves, Oven mitts, Anti-cut, } \\
\text { Gloves, Steel Mesh Gloves } \\
\text { CLOTHING: Semi-thermal pant, Ther ma } \\
\text { Blouse } \\
\text { HEAD: Headwear, Guar dian Headset }\end{array}$ \\
\hline
\end{tabular}

Source: The author 
The boning activity is developed by palette 06 employees, the same does not perform switching during postural activity of boning, as show in Figure 2. The prescribed task is:

- Receive the palette in the rolling table;

- Pull the same for fixed part of the bureau;

- Open the palette's tab with knife;

- Pull the bone, with partial shoulder extension;
- Accomplish the movement to turn the palette for bone exposure;

-Circumvent the bone, performing right shoulder abduction;

-Remove the meat adhered pallette (sudden movement);

-Put in the wake the palette boned and end the bone.

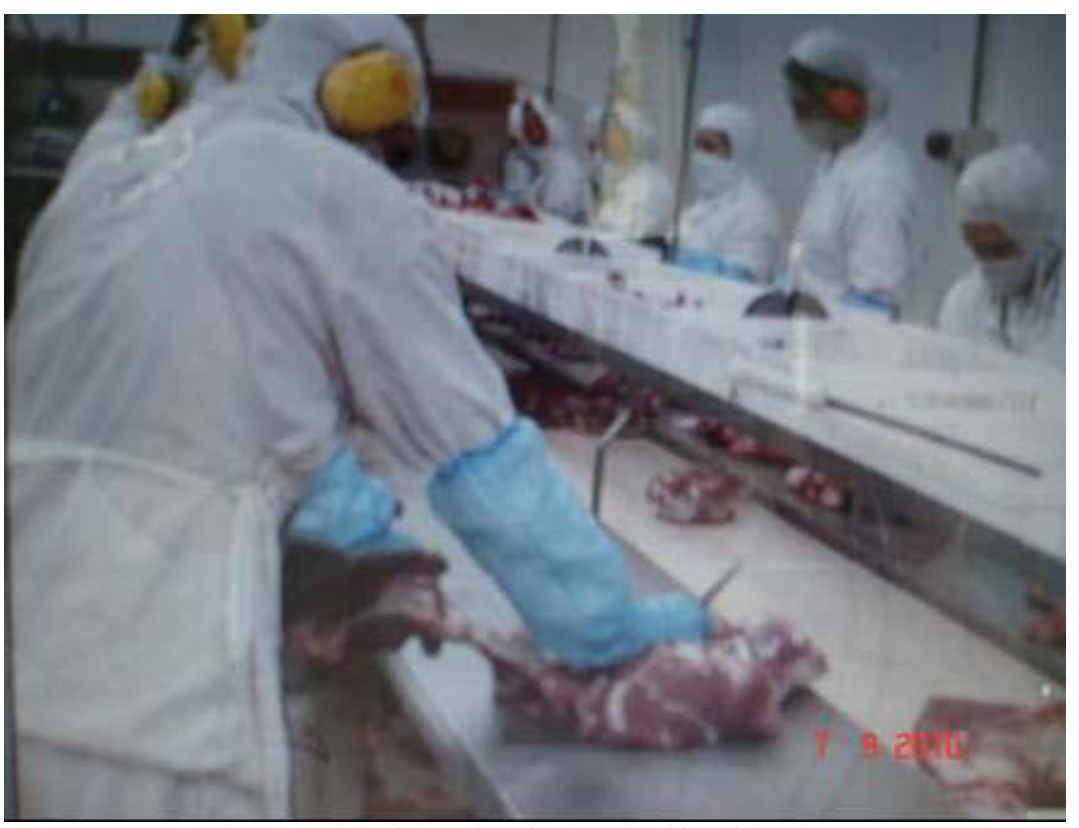

Figure 2. Line of the palette boning shoulder of the pig

Source: The author

\section{Results}

The next step of AET applied in this work includes the Analysis of Activities, Diagnosis and Ergonomics Recommendations focused on the work situation analysed.

After the initial demand survey, it was identified the body parts with a higher incidence of registration of pain: wrist, shoulder and lower back, and that these should be analyzed in ergonomic improvements.

\subsection{Analysis of activities}

The analysis of activities in this field survey consisted in monitoring the work of those involved with the boning of the palette, the application of questionnaires and evaluating method LEST physical charac teristics (anthropometric measures) as: age, height, elbow height, arm length between other.

The systems men-tasks are significantly richer systems that traditional human-machine systems, the tasks comprise not only the machinery and its manifestations (technical conditions of work), but also organizational and environmental conditions. When the ergonomics draws a distinction between task and activity, we find the basic structure of this template, it is necessary to describe in detail each step of the activity analyzed discrimination of the description of movements (see Figure 3). 


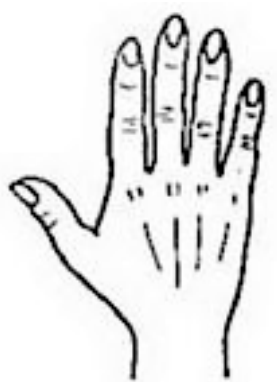

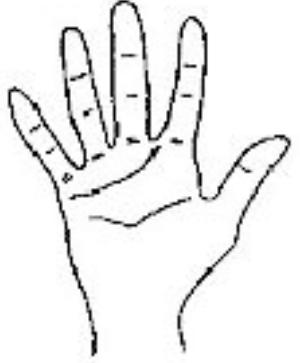

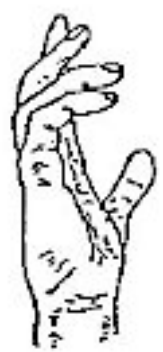

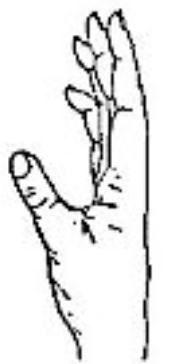

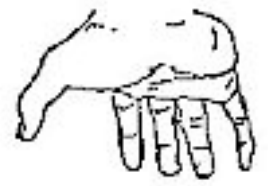

Figure 3. Possibilities of movement of hand and wrist Source: Lameira (2008)

To understand the entire workflow of bone activity palette was developed a step-by-step description, shows in detail the movement done each step of the process starting in pick up the entire palette of rolling table until the return of boned palette to the treadmill, to assessment of movements and repetitiveness in the actions.

The employee picks up the palette with the upper left and right together, brings up the workbench with bilateral bending of elbows and shoulder flexion, partial needs lean previously dependent on the location where the palette from the pull-down table. With the knife starts cutting by the inner part of the palette, opening it with elbow flexion, forearm pronated foot right shoulder abduction, and ulnar deviation of the wrist. The left upper limb, performs handles in pinch, elbow flexion and forearm neutral.

After starting the exposure of bone, secure grip on the bone with the hand, keeping the palette on foot to hold the bone removed from the meat on all sides of the palette. After open the palette, turns the same with the external part up, but partially boned and cut the inserts that still hold the bone meat. The left hand maintains grip, elbow flexion, forearm pronation now neutral now while the right hand holds the ulnar deviation of the wrist, flexion of wrist and elbow, shoulder abduction with flexion.

At the end of boning requires removing the bone from the palette, performing elbow flexion, extension of the shoulder, with the left upper limb, pulling the bone and with upper limb right polished vinyl on the bench for holding palette. Terminating the withdrawal supports bone at the tip of the bench and force down the left upper limb and removes the whole bone of meat boned palette. The bone remains in the hands of the employee and this plays in the rolling table and returns the boned palette with both hands to the table.

\subsection{LEST method}

After the review of field study it was found that the activity has high risk, and may generate complaints of pain in employees involved in the activity of boning of palette as exemplified in the graph in software e-LEST.

The LEST method seeks to determine comprehensively what are the working conditions, and how much and how they affect the health of the worker, meaning by "Health worker" a state of complete well-being, physical, mental and social.

The graph shows in Figure 4 presents the variables involved in day-to-day industry developer boning of palette: a static load, dynamic load, thermal environment, noise, lighting, attention, complexity, initiative, communication, social status and working time. 


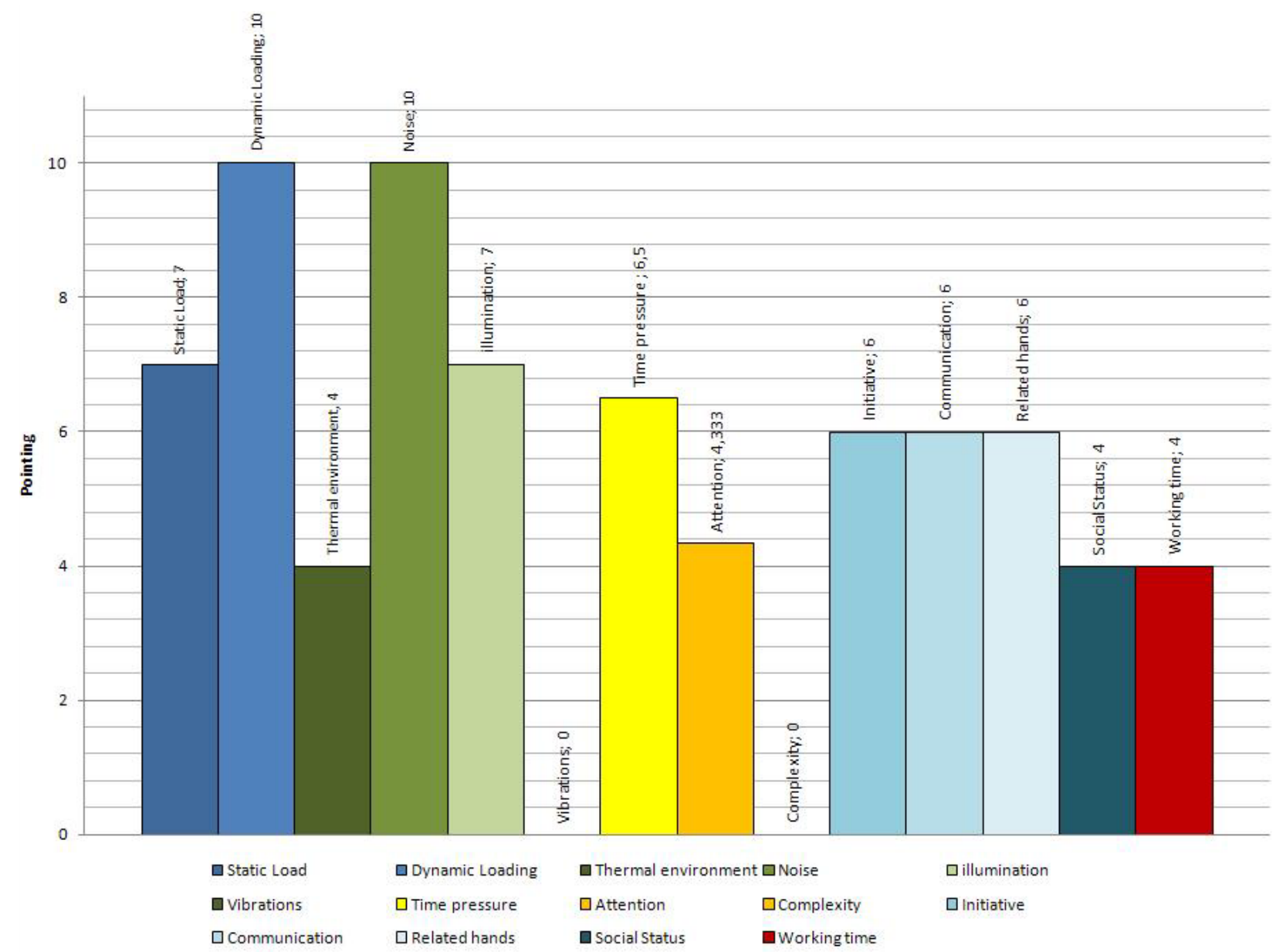

Figure 4. Histogram results of applying the LEST method Source: The author

By analyzing the histogram results of applying the LEST method, the main factors that contribute directly to the ergonomic risk of the activity of boning:

- Physical Load: Presented a result equal to nine and a highly elevated risk to the weight (palette with 8 pounds) and by repetitive activity.

- Physical Environment: work environment with little physical space resulting (ten points) contributed not only by poor performing the activity, but it also increases the risk of accidents. The main cause of this score is related with the local noise.

- Mental load: To perform the activity boning need attention to cutting patterns and perform the activity on the security requirements demanded by the company. In the evaluation the score was 3.61, thus the need to have employees report attention and care.

The most serious ones the aspects related to the physical environment and to the physical load. It is important to emphasize that none aspects were evaluated as satisfactory, what point to the necessity of immediate improvements in the work environment of the pig slaughter-house.

In addition to the analysis of the activity boning, it can identify, in an industrial system, a set of regulatory mechanisms developed formal and informal manner as: environmental conditions with low temperature, work with hand tools (knives), attention to perform the activity.

\section{Ergonomics recommendations}

After applying the tool AET in the activity of boning shoulder of the pig, using as support the LEST Method, immediate actions should be implemented to reduce complaints of pain and subsequent occupational diseases: 
-Development of effective rotation of activities that showed postural ergonomic risks;

-Proper training of the movement pattern made for boning and other movements that make up the rotation;

- Guidance to recovery workers and their attitudes;

- Breaks in situations of high repetitiveness of movements or static positioning of the body;

- Must give attention to adequate workers's protection of the exposition a highly noisy environment;

- Communication between staff and more direct charge of the sector.

As a result of ergonomic intervention in the enterprise were demonstrated a working environment with higher employee satisfaction and communicate more effectively and safety of employees involved in the activity analyzed.

\section{Conclusions}

From the collected results, data were analysed by LEST program, obtaining a diagnosis of the more relevant problems that affect the employees involved in the activity of boning of palette to propose better labour and health conditions to the workers of the pig slaughter-house.

The evaluation demonstrated an environment where workers are mainly exposed to noise and to loads of weight, pointing to some problems, detaching as the most serious ones the aspects related to the physical environment and to the physical load.

As results, it was identified the necessity of immediate intervention in the work station, because of the high risk of prejudice to the health of the workers.
Ergonomics recommendations for the working environment and activity must be improvement to satisfy the ergonomics requirements of NR 17 standard, attending the enterprise interests in the occupational diseases prevention.

\section{References}

[1] A. LAVILlE. Ergonomia. São Paulo EPU, Ed. da Universidade de São Paulo, 1997.

[2] A. P. LAMEIRA, S. GUIMARÃES-SILVA, F. M. FERREIRA, L. V. LIMA, A. PEREIRA JR, L. G. GAWRYSZEWSKI. Hand posture and motor imagery: a body part recognition study. Rev Bras Fisioter, São Carlos, v. 12, n. 5, p. 379-85, Sept./Oct. 2008.

[3] F. A. PINHEIRO, B. T. TROCCOLO, C. V. CARVAlHO Validação do questionário de Sintomas Osteomusculares como medida de morbilidade. Re. Saúde Publica 2002.

[4] H A COUTO. Novas Perspectivas na Abordagem Preventiva das LER/DORT. Belo Horisonte: Ergo - UFMG/ FACE 2002

[5] H. A. COUTO. Ergonomia aplicada ao trabalho em 18 lições. Belo Horizonte: Ergo, 2002.

[6] I. IIDA. Ergonomia; projeto e produção. São Paulo: 2 ed. Edgard Blucher, 2005.

[7] ILO. The ILO Programme on Occupational Safety and Health in Agriculture. International Labour Office. Genebra. 1999. Disponível em www.ilo.org. Acesso em 27.10.2009.

[8] L. ULBRICHT. Fatores de Risco Associados à Incidência dos DORT entre Ordenhadores em Santa Catarina. Florianópolis, 2003. Tese de Doutorado apresentada ao Curso de PósGraduação em Engenharia de Produção, UFSC. Florianópolis, 2003.

[9] MÉTODO LEST. Available on $<$ http://www.ergonautas.upv.es/metodos/lest/lest-ayuda.php $>$. Accessed on May 29th, 2011.

[10]MTE. Manual de Aplicação da Norma Regulamentadora $n^{\circ}$ 17 - 2 ed. - Brasília: MTE, SIT, 2002.

[11]N. SANTOS, A.R. DUTRA, F. FIALHO, R. P. PROENÇA. Antropotecnologia: a ergonomia dos sistemas de produção. Curitiba: Genesis, 1997.

[12]N. SANTOS. Manual de Análise Ergonômica do Trabalho. 2.ed. Curitiba: Genesis, 1997. 